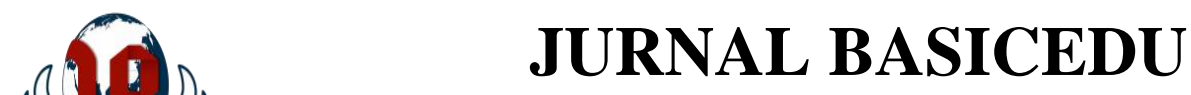

Volume 5 Nomor 4 Tahun 2021 Halaman 1985 - 1997

Research \& Learning in Elementary Education

https://jbasic.org/index.php/basicedu

PNIVERSITAS

\title{
Pelaksanaan Evaluasi Pembelajaran secara Daring pada Belajar dari Rumah (BDR) jenjang Sekolah Menengah Pertama (SMP)
}

\author{
Annisa Sri Wandini ${ }^{1 凶}$, Fitriani Yustikasari Lubis $^{2}$ \\ Fakultas Psikologi Universitas Padjadjaran, Jatinangor ${ }^{1,2}$ \\ E-mail: annisa14025@mail.unpad.ac.id ${ }^{1}$
}

\begin{abstract}
Abstrak
Penelitian ini bertujuan untuk mengkaji penerapan peran komponen yang terlibat dalam evaluasi pembelajaran daring pada BDR jenjang SMP. Pendekatan exploratory sequential mixed method digunakan dalam penelitian ini. Partisipan merupakan guru SMP dari beberapa Provinsi di Indonesia, terdiri dari 11 orang guru yang berpartisipasi pada metode Focus Group Discussion yang dianalisis secara tematik dengan pendekatan kualitatif dan 18 orang guru yang berpartisipasi pada metode kuesioner yang diolah secara kuantitatif. Hasil penelitian pada setiap komponen dalam evaluasi pembelajaran menunjukkan bahwa: (1) Kurikulum memberikan arahan dan referensi dengan adanya otonomi dan fleksibilitas untuk dikembangkan oleh guru sesuai situasi daerah setempat dan satuan pendidikan, (2) Guru memiliki kemampuan dalam menggunakan metode dan media evaluasi, tetapi masih diperlukan upaya untuk melakukan kolaborasi antara guru dengan mata pelajaran yang berbeda ketika memberikan tugas untuk meminimalisir jumlah tugas, (3) Siswa memberikan respon tidak mengerjakan atau terlambat mengumpulkan tugas karena merasa terbebani dengan banyaknya jumlah tugas yang harus dikerjakan bersamaan dengan kewajiban mengikuti KBM di kelas, (4) Peran monitoring orang tua dalam pengerjaan dan penyelesaian tugas masih perlu ditingkatkan, serta (5) Perlunya fasilitas pemantauan tugas yang dapat diakses baik oleh guru, siswa dan orang tua sehingga peran setiap komponen dalam melakukan evaluasi lebih terintegrasi dan proses evaluasi dapat memberikan data yang lebih akurat.
\end{abstract}

Kata Kunci: Evaluasi Pembelajaran Daring, Belajar dari Rumah, Sekolah Menengah Pertama.

\begin{abstract}
This study aims to explain the role of components involved in the evaluation of online learning (School from home) in Junior High School. The exploratory sequential mixed method approach was used in this study. Participants are teachers from several provinces in Indonesia consist of 11 teachers who participated in Focus Group Discussion that was analyzed thematically and 18 teachers who participated in filling Questionnaire that was analyzed quantitatively. The results on each component show that: (1) The curriculum provides direction and reference with the autonomy and flexibility for teacher to implement according to the local situation and schools, (2) Teachers have competence in using evaluation methods and media, but the collaboration between teachers of different subjects is needed to minimize the number of assignments, (3) Students are not doing the assignments or late in collecting assignments because they feel overwhelmed by the high number of tasks that must be done while attending online learning class, (4) The role of parent monitoring in completing assignments needs to be improved, (5) The need for assignment monitoring facilities that can be accessed by teachers, students and parents so that the role of components in online learning evaluation is more integrated and provide more accurate data.
\end{abstract}

Keywords: Evaluation for Learning, Online Evaluation, High School.

Copyright (c) 2021 Annisa Sri Wandini, Fitriani Yustikasari Lubis

Corresponding author :

Email : annisa14025@mail.unpad.ac.id

DOI $\quad:$ https://doi.org/10.31004/basicedu.v5i4.1113

ISSN 2580-3735 (Media Cetak)

ISSN 2580-1147 (Media Online)

Jurnal Basicedu Vol 5 No 4 Tahun 2021

p-ISSN 2580-3735 e-ISSN 2580-1147 


\section{PENDAHULUAN}

Evaluasi pembelajaran merupakan proses pengumpulan data dan informasi dalam membuat keputusan mengenai aktivitas-aktivitas pembelajaran meliputi program, kurikulum, metode pembelajaran dan aktivitas sekolah lainnya (Gage \& Berliner, 1998). Evaluasi pembelajaran bertujuan untuk mengetahui efektivitas dan efisiensi sistem pembelajaran, meliputi tujuan, materi, metode, media, sumber belajar, lingkungan belajar dan sistem penilaian dalam pembelajaran, serta mengetahui tingkat pengetahuan, keterampilan, sikap dan nilainilai siswa untuk jenis pendidikan tertentu (Arifin, 2012). Evaluasi yang baik dapat digunakan dalam membuat keputusan mengenai siswa, memberikan umpan balik pada siswa mengenai kemajuan, kekuatan, dan kelemahannya, menilai efektivitas proses instruksi dan menginformasikan kebijakan pendidikan (Gagné et al., 2005). Secara umum, terdapat dua jenis evaluasi pembelajaran, yaitu: (1) Formative Evaluation, yaitu evaluasi yang dilakukan sebagai dasar untuk memperbaiki material atau program dan keefektifan strategi instruksional yang sedang dilakukan untuk membantu guru meningkatkan proses belajar mengajar yang dilakukan saat ini, dan (2) Summative Evaluation yaitu penilaian suatu program pembelajaran sebagai dasar menilai seberapa baik suatu program memberikan hasil yang diharapkan untuk meningkatkan proses pembelajaran di masa mendatang (Gage \& Berliner, 1998; Gagné et al., 2005; Tobin et al., 2015).

Berdasarkan pedoman Belajar dari Rumah (BDR) yang dikeluarkan oleh Kemdikbud sebagai kebijakan pendidikan dalam masa darurat penyebaran pandemi Covid-19 melalui Surat Edaran (SE) Sekretaris Jenderal No. 15 Tahun 2020, dijelaskan mengenai langkah-langkah yang harus dilakukan guru, siswa dan orang tua setelah pembelajaran, misalnya guru mengingatkan orang tua untuk mengumpulkan foto lembar aktivitas dan penugasan, guru memberikan umpan balik terhadap hasil karya/tugas/lembar refleksi pengalaman belajar siswa, siswa mengumpulkan dokumentasi/foto pembelajaran harian, serta orang tua berdiskusi dengan guru terkait kendala yang dihadapi selama pembelajaran. Pedoman pelaksanaan belum menjelaskan secara konkrit mengenai bagaimana metode, instrumen evaluasi dan proses pemberian dan pengolahan nilai membuat guru harus mengembangkannya secara mandiri berdasarkan kebutuhan dan situasi satuan pendidikan masingmasing. Berdasarkan asesmen yang dilakukan oleh Pemerintah Jawa Barat terhadap siswa dan orang tua siswa menunjukkan bahwa orang tua mengalami kesulitan untuk mendampingi anak belajar di rumah karena materi pembelajaran dan kesibukan dan siswa mengalami kesulitan memahami tugas yang diberikan guru, merasa bosan, kurang konsentrasi, sulit berkomunikasi dengan guru dan kurang jelasnya tugas yang diberikan guru sehingga siswa mengharapkan tugas yang tidak membebani, terencana dan terjadwal baik sebagai metode pembelajaran atau evaluasi belajar siswa (Disdik Jabar, 2020).

Peneliti melakukan studi pendahuluan terhadap 117 guru SMP dari berbagai provinsi di Indonesia menggunakan survei daring mengenai pelaksanaan proses belajar mengajar pada pembelajaran BDR dan mendapatkan temuan bahwa setelah merancang dan melakukan pembelajaran menggunakan metode dan media daring yang telah dilakukan, adanya kesulitan untuk melakukan proses evaluasi pembelajaran dengan metode daring, misalnya ketika melihat aspek non-kognitif siswa dari proses mengerjakan tugas sebagai metode utama evaluasi pembelajaran, memastikan hasil pekerjaan siswa menggambarkan kemampuannya dan memanfaatkan media daring. Hal ini juga sejalan dengan penelitian Fitrah \& Ruslan (2020) yang menjelaskan bahwa selama melaksanakan evaluasi pembelajaran di masa pandemi Covid-19 ini guru dihadapkan berbagai masalah, seperti desain instrumen masih dirasa kebingungan oleh guru, partisipasi siswa rendah, keaktifan siswa lemah, pemahaman siswa terhadap soal kurang, soal tanpa penjelasan, kuota internet lemah, keterampilan guru, siswa, dan orang tua lemah, dan lainnya. Berdasarkan penjelasan diatas, evaluasi pembelajaran ini memegang peranan yang penting untuk keberlangsungan proses pembelajaran di jenjang SMP. Adanya perubahan evaluasi pembelajaran yang umumnya dilakukan secara tatap muka dan sekarang bergeser menjadi evaluasi pembelajaran BDR memberikan kendala-kendala tertentu pada pihak sekolah, siswa dan orang tuanya. Hal ini diantaranya karena pelaksanaan evaluasi pembelajaran daring bukan hanya 
1987 Pelaksanaan Evaluasi Pembelajaran secara Daring pada Belajar dari Rumah (BDR) jenjang Sekolah Menengah Pertama (SMP) - Annisa Sri Wandini, Fitriani Yustikasari Lubis

DOI: https://doi.org/10.31004/basicedu.v5i4.1113

sekedar memindahkan evaluasi pembelajaran tatap muka menjadi digital melainkan terdapat perubahan yang lebih esensial.

Menurut (Tobin et al., 2015) terdapat perbedaan tantangan antara evaluasi pembelajaran secara daring dan tatap muka, yaitu: (1) Scope, pada pembelajaran daring batasan antara dalam dan luar kelas menjadi samar karena interaksi antara siswa, guru dan materi belajar terjadi di berbagai lokasi sehingga jangkauan evaluasi menjadi lebih luas, (2) Time Equivalence, evaluator harus menentukan berapa banyak dan kapan saja proses observasi akan dilakukan karena luasnya jangkauan evaluasi, (3) Separating Teaching from Design, perilaku siswa dan media yang digunakan sebagai alat bantu menjadi tidak terpisahkan sehingga adanya kecenderungan untuk melihat hasil yang ditunjukkan siswa sebagai perilaku siswa dalam belajar, (4) Measurement equivalence, sikap yang tampak, volume, body language dan aspek-aspek material lainnya menjadi tidak tampak sehingga dapat dilihat berdasarkan respon dalam menjawab pertanyaan, interaksi selama belajar, derajat conceptual scaffolding selama diskusi dan tingkatan cognitive domain yang ingin dicapai, (5) Instrument Applicability, mengadaptasi secara langsung instrumen tatap muka untuk pembelajaran daring dapat menghasilkan measurement error dan unintentional bias, (6) Scalability, pembelajaran daring lebih dapat diskalakan daripada tatap muka.

Selain perbedaan esensi dari daring dan tatap muka, terdapat komponen-komponen yang perlu menjadi perhatian dalam pelaksanaan evaluasi pembelajaran. Hodges et al. (2020) menjelaskan bahwa keberhasilan suatu pembelajaran secara daring melibatkan lebih dari sekadar aspek instruksional yang dilakukan melainkan keterikatan siswa dalam pembelajaran dan dukungan sosial yang dirasakan sehingga membutuhkan peran berbagai komponen yang terlibat secara keseluruhan, mulai dari infrastruktur (ketersediaan perpustakaan, akses di rumah masing-masing, serta fasilitas kesehatan yang berbeda-beda untuk setiap siswa) hingga sumber daya lingkungan (situasi lingkungan tempat belajar dan dukungan sosial di sekitar). Moore et al. (2002) juga menjelaskan bahwa tantangan sistem evaluasi pada pembelajaran daring adalah terlibatnya kesatuan yang kompleks antara infrastruktur dan personil dengan mempertimbangkan faktor instruksional, teknologi, implementasi dan organisasi yang meskipun bersifat independen tetapi harus bekerjasama secara efektif agar sistem dapat berjalan secara menyeluruh. Hal ini menunjukkan bahwa pentingnya untuk melihat evaluasi belajar secara daring berdasarkan setiap komponen yang terlibat dalam evaluasi belajar.

Secara praktis, Kemdikbud sudah menetapkan bagaimana peran satuan pendidikan, guru, siswa dan orang tua dalam mengelola evaluasi pembelajaran dengan metode dan fasilitas yang diperlukan berdasarkan arahan kurikulum yang dapat dikembangkan. Perbedaan tantangan faktor instruksional (Tobin et al., 2015) dan lingkungan pembelajaran siswa yang bervariasi pada evaluasi pembelajaran secara daring menyebabkan pedoman yang sudah diberikan tidak bisa langsung diterapkan di lapangan, misalnya ketika pedoman menjelaskan peran orang tua untuk mendampingi siswa belajar di rumah tetapi adanya perbedaan kemampuan siswa untuk melakukannya, serta perbedaan fasilitas yang dimiliki oleh setiap siswa dalam mendukung pelaksanaan evaluasi pembelajaran. Perbedaan dalam proses pelaksanaan evaluasi pembelajaran secara daring dan tatap muka menjadikan penting untuk mengetahui bagaimana gambaran penerapan peran pelaksanaan komponen-komponen yang terlibat dalam evaluasi pembelajaran BDR, yaitu; (1) Kurikulum sebagai komponen landasan pengembangan program KBM yang akan diukur, (2) Guru sebagai komponen yang melakukan pengambilan data untuk mengukur ketercapaian tujuan program, (3) Siswa sebagai komponen yang diambil datanya, (4) Orang tua sebagai komponen yang dalam pembelajaran daring menjadi lebih luas fungsinya dalam pendampingan siswa, dan (5) Fasilitas sebagai komponen penunjang. Oleh karena itu, peneliti ingin mengetahui pelaksanaan evaluasi pembelajaran secara daring pada BDR jenjang SMP untuk mendapatkan gambaran penerapan peran pelaksanaan komponen-komponen yang terlibat dan memahami permasalahan yang terjadi dan alternatif solusi pada proses evaluasi pembelajaran secara daring. 


\section{METODE PENELITIAN}

Penelitian ini menggunakan pendekatan exploratory sequential mixed method (Creswell \& Creswell, 2018) dalam menggambarkan bagaimana penerapan peran pelaksanaan komponen-komponen yang terlibat dalam evaluasi pembelajaran secara daring pada BDR jenjang SMP untuk memahami permasalahan yang terjadi pada proses evaluasi pembelajaran secara daring. Partisipan merupakan guru SMP dari beberapa Provinsi di Indonesia (Sumatera Barat, Kepulauan Riau, Lampung, Jawa Barat, Jawa Tengah dan Jawa Timur,) yang terdiri dari berbagai jenjang (kelas VII, VIII dan IX), mata pelajaran (Bimbingan Konseling, Matematika, Bahasa Indonesia, Bahasa Inggris, IPA, PJOK dan Al-Qur'an) dan jenis sekolah (negeri dan swasta). Partisipan dipilih berdasarkan kesediaan untuk mengikuti asesmen berdasarkan informasi yang disebarkan melalui alamat $e$-mail guru yang berpartisipasi pada survei awal dan media sosial. Pengambilan data dilakukan pada Desember 2020-Januari 2021.

Pada tahap penelitian kualitatif, metode yang digunakan diawali dengan Focus Group Discussion (FGD) yang dilakukan oleh 11 orang guru. FGD berlangsung selama 120 menit dengan pertanyaan yang dikembangkan peneliti berdasarkan konsep evaluasi pembelajaran Gage \& Berliner (1998) dan evaluasi pembelajaran secara daring Tobin et al. (2015), yaitu: (1) Panduan yang selama ini digunakan ketika melakukan evaluasi pembelajaran secara daring, (2) Pelaksanaan evaluasi pembelajaran secara daring yang sudah dilakukan, (3) Peran orang tua dalam evaluasi pembelajaran secara daring, dan (4) Apa yang sudah dilakukan sehingga evaluasi pembelajaran dapat terlaksana dengan baik. Data yang diperoleh berupa audio ditranskrip menjadi teks kemudian dilakukan analisis data menggunakan metode tematik untuk mengelompokkan teks kepada makna yang sama (Howitt, 2010). Proses pengkodingan dilakukan berdasarkan lima komponen evaluasi pembelajaran secara daring, yaitu kurikulum, guru, siswa, orang tua dan fasilitas.

Pada tahap penelitian kuantitatif, data diperoleh melalui kuesioner yang diisi oleh 18 orang guru, terdiri dari 7 orang guru yang juga berpartisipasi dalam FGD dan 11 orang guru yang hanya mengisi kuesioner. Kuesioner dalam bentuk pertanyaan dengan pilihan jawaban yang dapat dipilih lebih dari satu diolah secara kuantitatif menggunakan perhitungan frekuensi untuk mengkonfirmasi dan memperkuat data yang didapatkan dari FGD. Data hasil penelitian kualitatif dan kuantitatif kemudian dianalisis dan dilakukan peer review melalui diskusi panel untuk mengkaji kesamaan data yang didapatkan dan menarik kesimpulan. Peer review dilakukan oleh 5 orang dengan kualifikasi 3 orang dosen Psikologi Pendidikan dan 2 orang Mahasiswa Magister Psikologi Profesi

\section{HASIL DAN PEMBAHASAN}

Hasil penelitian terdiri dari hasil analisis secara kualitatif dan kuantitatif. Berikut dijelaskan hasil analisis secara kualitatif menggunakan FGD yang memberikan gambaran mengenai pelaksanaan peran komponen-komponen yang terlibat dalam evaluasi pembelajaran secara daring pada BDR jenjang SMP berdasarkan pengalaman dan pandangan guru dengan memberikan hasil berupa kesulitan dan keberhasilan yang dirasakan. Hasil FGD menghasilkan total 27 tema secara keseluruhan yang ringkasannya tergambar pada Tabel 1.

Tabel 1. Hasil Analisa Data

\begin{tabular}{llc}
\hline \multicolumn{1}{c}{ Komponen } & \multicolumn{1}{c}{ Tema } & Jumlah* \\
\hline \multirow{2}{*}{ Kurikulum } & Metode tugas (waktu pengumpulan tertentu) & 11 \\
\cline { 2 - 3 } & Metode ujian (formulir secara daring) & 4 \\
\cline { 2 - 3 } & Kurikulum disederhanakan & 4 \\
\cline { 2 - 3 } & Mengembangkan kurikulum kondisi khusus & 4 \\
\cline { 2 - 3 } & Mengikuti arahan Disdik setempat & 3 \\
\hline \multirow{2}{*}{ Guru } & Guru mendengarkan pendapat orang tua & 6 \\
\cline { 2 - 3 } & Guru memberikan kelonggaran & 6 \\
\hline
\end{tabular}




\begin{tabular}{|c|c|c|}
\hline & Guru mapel tetap menuntut target/syarat ketuntasan & 5 \\
\hline & Wali kelas berperan penting & 5 \\
\hline & Guru kesulitan mengamati perilaku siswa (BK) & 2 \\
\hline \multirow{7}{*}{ Siswa } & Siswa tidak mengerjakan tugas & 10 \\
\hline & Siswa terlambat mengumpulkan tugas & 7 \\
\hline & Siswa membohongi orang tua/guru & 7 \\
\hline & Hasil tugas siswa tidak sesuai harapan/nilai menurun & 6 \\
\hline & Siswa bolos KBM/main game/kebiasaan tidur berubah & 6 \\
\hline & Siswa tampak bosan, stress dan terbebani tugas & 6 \\
\hline & Siswa mengerjakan ketika tidak merasa terbebani dengan tugas & 3 \\
\hline \multirow[t]{5}{*}{ Orang Tua } & Orang tua kurang berpartisipasi (sibuk) & 7 \\
\hline & Orang tua menyampaikan kendala & 5 \\
\hline & Orang tua jenuh/terbebani/kendala pribadi & 5 \\
\hline & Perbedaan latar belakang orang tua & 4 \\
\hline & Orang tua kasihan melihat anak & 2 \\
\hline \multirow[t]{5}{*}{ Fasilitas } & Media grup WhatsApp mata pelajaran & 7 \\
\hline & Media LMS (Google classroom/Aplikasi sekolah) & 7 \\
\hline & Media interaksi dua arah (Google meet /Zoom meeting/dsb) & 6 \\
\hline & Luring ke sekolah (terkendala fasilitas) & 4 \\
\hline & Kendala sinyal & 3 \\
\hline
\end{tabular}

*Keterangan: Jumlah tema disebutkan selama diskusi

Sumber: Data Primer FGD

Berdasarkan tema yang dihasilkan pada Tabel 1 menunjukkan bahwa terdapat lima komponen yang memiliki peran dalam melakukan evaluasi pembelajaran secara daring. Pada komponen kurikulum, metode tugas dengan waktu pengumpulan tertentu merupakan metode evaluasi utama yang dilakukan hampir seluruh guru yang mengikuti diskusi dan sebagian guru melakukan metode ujian menggunakan formulir yang diakses secara daring. Beberapa guru secara spesifik juga membahas mengenai pengembangan kurikulum kondisi khusus yang disesuaikan situasi berdasarkan arahan Dinas Pendidikan setempat, serta kurikulum disederhanakan dengan lebih berfokus pada kompetensi inti dan pengembangan keterampilan atau life-skills.

Pada komponen guru dijelaskan mengenai upaya-upaya yang dilakukan selama proses evaluasi, yaitu mendengarkan pendapat orang tua dengan cara melakukan komunikasi melalui grup WhatsApp dengan menyediakan sarana orang tua menyampaikan kendala dan mengadakan pertemuan daring. Beberapa guru memberikan kelonggaran, melalui pemberian 'nilai kasihan' atau hanya menilai dari kehadiran meskipun beberapa guru juga merasa penting untuk menjaga kualitas dengan mencapai target/syarat ketuntasan. Wali kelas juga menjadi komponen penting untuk guru mapel berkoordinasi dengan siswa dan orang tua selama proses BDR berlangsung

Komponen siswa menjadi bahasan yang paling banyak disebutkan, khususnya mengenai respon siswa terhadap tugas. Kebanyakan siswa tidak mengerjakan tugas, terlambat mengerjakan tugas dan hasil tugas yang kurang memuaskan. Guru mengatakan sudah mencoba memberikan keringanan tetapi tetap kesulitan, misalnya "sudah mencoba memberi toleransi bahwa siswa hanya cukup mengerjakan tetapi tetap tidak bisa diharapkan", "masih banyak laporan siswa tidak mengumpulkan tugas dan hasil belajar siswa tidak sesuai harapan" dan "nilai raport banyak nilai kasih sayang tetapi jika tidak dikerjakan sama sekali, tidak ada nilai yang bisa diberikan". Guru menyadari bahwa siswa merasa terbebani dengan tugas yang diberikan, misalnya "Siswa stress luar biasa dengan ulangan formatif, ulangan harian dan tugas pada saat yang bersamaan", "ada grup KM tempat siswa menyampaikan kendala dan masukan ketika siswa mengalami kesulitan karena banyak tugas" dan "Orang tua mengatakan terlalu banyak tugas dan kasihan kepada siswanya." Siswa juga menunjukkan perilaku kurang sesuai, seperti bolos Kegiatan Belajar Mengajar (KBM), menggunakan gawai bukan untuk belajar melainkan bermain game dan kebiasaan tidur yang berubah karena tidak ada tuntutan 
untuk datang secara langsung ke sekolah. Ditemukan beberapa fakta bahwa siswa membohongi guru dan/atau orang tua bahwa sedang atau sudah menyelesaikan tugas.

Pada komponen orang tua, beberapa orang tua menyampaikan kendala mengenai kesulitan mendampingi siswa selama BDR sedangkan beberapa orang tua lain kurang berpartisipasi karena sibuk bekerja dan tidak menghadiri pertemuan guru dan orang tua. Beberapa orang tua bahkan juga mengalami kejenuhan/terbebani dan adanya perbedaan latar belakang orang tua menyebabkan guru dan/atau orang tua kesulitan untuk bekerjasama dalam mendampingi siswa. Pada komponen fasilitas, proses evaluasi belajar sudah menggunakan berbagai media yang dapat membantu evaluasi dan didominasi grup WhatsApp mata pelajaran, serta aplikasi lain seperti Google Meet, Google Classroom dan Google Form. Beberapa sekolah sudah mulai menggunakan aplikasi daring sebelum terjadi pandemi dan menyediakan fasilitas luring ke sekolah untuk siswa yang terkendala jaringan.

Berikutnya penjelasan mengenai hasil analisis secara kuantitatif menggunakan kuesioner yang memberikan beberapa hasil temuan berupa berupa panduan evaluasi pembelajaran secara daring dari kurikulum pada Gambar 1, peran orang tua dalam evaluasi pembelajaran secara daring pada Gambar 2, serta keterampilan melakukan evaluasi pembelajaran secara daring yang sudah dimiliki guru pada Gambar 3.

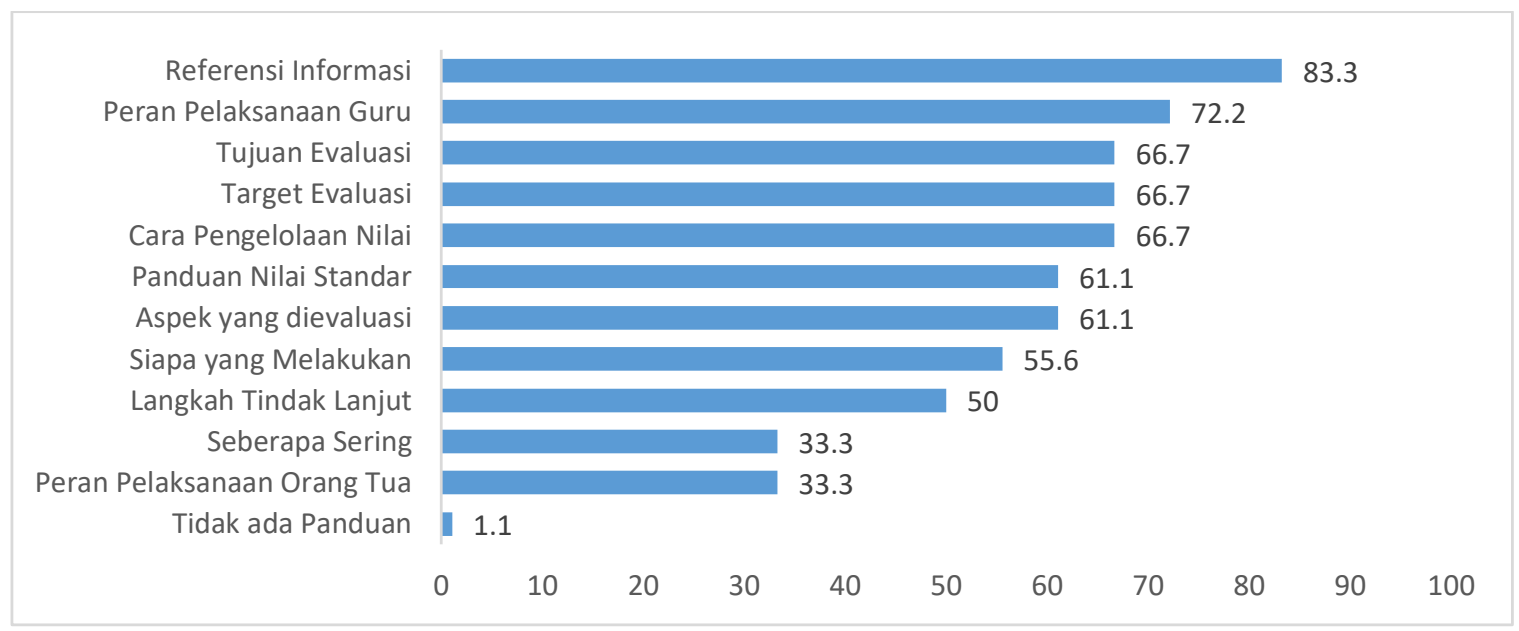

Gambar 1. Panduan Evaluasi Pembelajaran secara Daring dari Kurikulum (\%)

Gambar 1 menunjukkan bahwa kurikulum memberikan penjelasan mengenai panduan evaluasi pembelajaran meskipun terdapat perbedaan hal yang dijelaskan di dalamnya. Kurikulum paling banyak memberikan penjelasan mengenai referensi informasi untuk mengembangkan panduan evaluasi $(83,3 \%)$ dan peran pelaksanaan guru dalam evaluasi secara daring $(72,2 \%)$ dan paling sedikit terkait seberapa sering melakukan evaluasi $(33,3 \%)$ dan peran pelaksanaan orang tua dalam proses evaluasi $(33,3 \%)$, serta ada yang mengatakan tidak ada panduan (5,6\%). Data kuesioner juga menunjukkan bahwa mayoritas guru mengembangkan panduan evaluasi pembelajaran (22,2\% tidak mengembangkan). 

Menengah Pertama (SMP) - Annisa Sri Wandini, Fitriani Yustikasari Lubis

DOI: https://doi.org/10.31004/basicedu.v5i4.1113

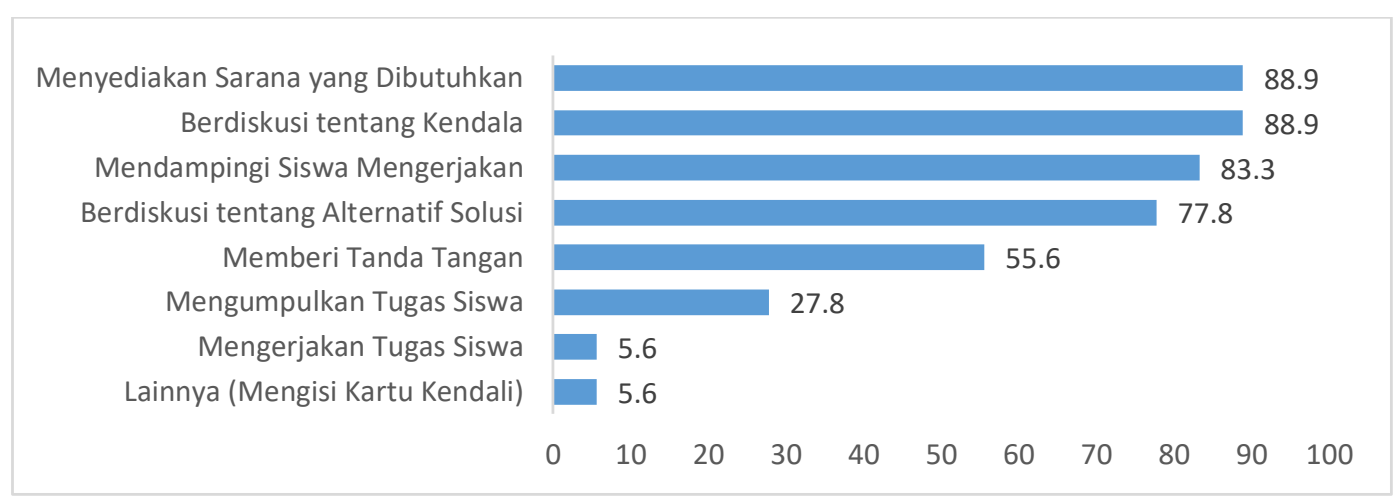

Gambar 2. Peran Orang Tua dalam Evaluasi Pembelajaran secara Daring (\%)

Gambar 2 menunjukkan bahwa orang tua berperan pada evaluasi pembelajaran secara daring. Orang tua paling banyak melakukan diskusi secara aktif terkait tantangan dan kendala yang dialami $(88,9 \%)$ dan menyediakan sarana yang dibutuhkan $(88,9 \%)$, serta mendampingi siswa mengerjakan tugas $(83,3 \%)$.

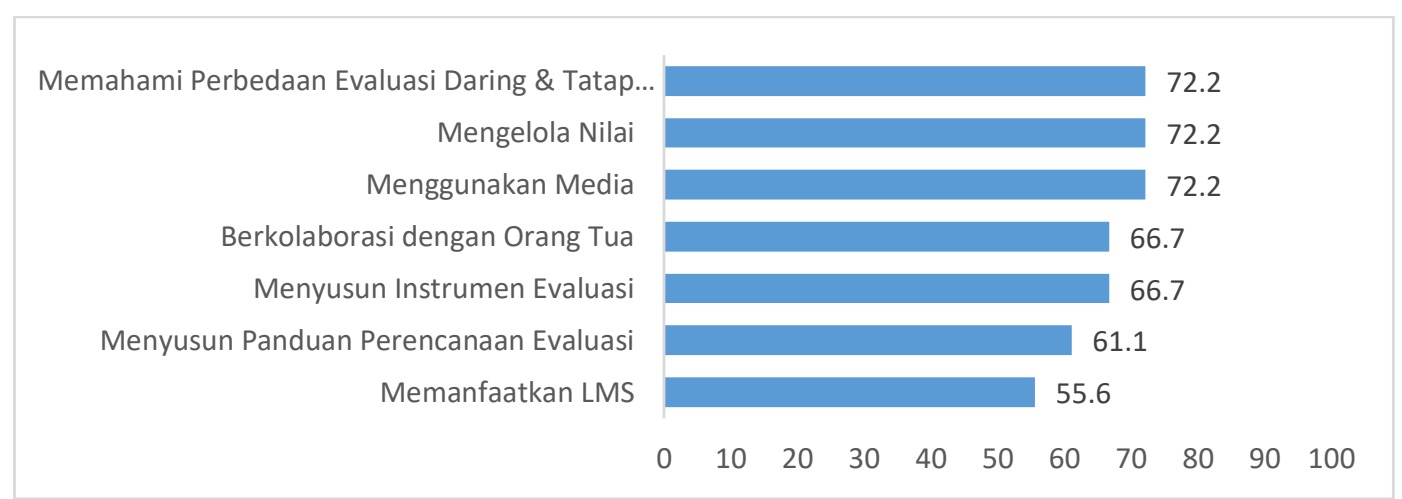

Gambar 3. Keterampilan Melakukan Evaluasi Pembelajaran secara Daring yang Sudah Dimiliki Guru (\%)

Gambar 3 menunjukkan bahwa secara umum 60-73\% guru memiliki keterampilan-keterampilan yang dibutuhkan untuk melakukan evaluasi belajar secara daring. Keterampilan yang dirasa paling mampu adalah mengelola nilai, memahami perbedaan evaluasi daring dan tatap muka dan menggunakan media evaluasi secara daring.

Peneliti akan mengkaji pelaksanaan evaluasi pembelajaran berdasarkan fase perencanaan, pelaksanaan dan setelah evaluasi pada masing-masing komponen yang terlibat dalam evaluasi pembelajaran secara daring dan pengaruhnya terhadap proses evaluasi pembelajaran dengan tujuan menggambarkan bagaimana penerapan peran komponen-komponen yang untuk memahami permasalahan yang terjadi pada proses evaluasi pembelajaran secara daring.

\section{Komponen Kurikulum}

Kurikulum acuan dalam melakukan evaluasi pembelajaran secara daring adalah kurikulum berdasarkan kebijakan Nasional BDR dan pedoman yang dijadikan panduan pelaksanaan yang dikeluarkan oleh pemerintah. Kurikulum 2013 (K-13) disederhanakan dengan memfokuskan pada kompetensi inti tanpa paksaan untuk menuntaskan kurikulum dan lebih fokus pada kecakapan hidup dan kesejahteraan siswa. Panduan yang digunakan berisi metode dan media pembelajaran BDR dengan beberapa website referensi mengenai konten dan media yang dapat digunakan, serta panduan pelaksanaan untuk Dinas Pendidikan, 
kepala sekolah, guru, siswa, dan orang tua/wali. Pada panduan pelaksanaan dituliskan peran masing-masing pihak pada sebelum, saat dan setelah pembelajaran secara umum (Kemdikbud, 2020). Kemudian pemerintah memberikan fleksibilitas dan otonomi setiap SMP di daerah masing-masing untuk dapat mengembangkan dan menerapkan kurikulum dengan menyesuaikan pada situasi sekolah masing-masing.

Hal ini sejalan dengan pengembangan sistem evaluasi belajar daring menurut Tobin et al. (2015) dengan proses (1) Mengidentifikasi kebijakan institusi yang mempengaruhi aspek evaluasi, terdiri atas nilai yang dimiliki institusi terhadap pembelajaran daring, struktur pembelajaran daring yang dilakukan, peran otoritas dalam menerima sistem evaluasi, pengaruh dana terhadap keputusan evaluasi, serta hambatan institusi/organisasi/program yang akan dihadapi; (2) Menilai implementasi kebijakan yang memberikan arah pada struktur evaluasi. terdiri atas siapa yang bertanggung jawab dalam melakukan evaluasi, apakah stakeholders memiliki keahlian yang sesuai dengan pembelajaran daring, komponen yang akan dievaluasi, target evaluasi, seberapa sering evaluasi dilakukan, serta data apa yang akan dikumpulkan dan data tambahan apa yang akan dibutuhkan; serta (3) Menentukan bagaimana data evaluasi pembelajaran akan digunakan, terdiri atas penyeimbangan penggunaan data dari berbagai stakeholders atau sumber, bagaimana waktu evaluasi mempengaruhi nilai dari informasi yang tersedia, keputusan yang akan diambil berdasarkan data yang ada, serta apakah evaluasi pembelajaran daring akan dipisahkan dengan evaluasi secara umum.

Pada saat pelaksanaan, otonomi untuk mengembangkan kurikulum menyebabkan perbedaan konten panduan untuk setiap sekolah. Data menunjukkan bahwa kurikulum paling banyak memberikan penjelasan mengenai referensi informasi untuk mengembangkan panduan evaluasi $(83,3 \%)$ dan peran pelaksanaan guru dalam evaluasi secara daring $(72,2 \%)$ sedangkan paling sedikit terkait seberapa sering melakukan evaluasi $(33,3 \%)$ dan peran pelaksanaan orang tua dalam proses evaluasi $(33,3 \%)$. Hal ini juga terjadi karena SMP berada pada kewenangan Dinas Pendidikan Kabupaten/Kota daerah masing-masing dan tidak semua Dinas Pendidikan mengeluarkan panduan spesifik dan praktis untuk dilakukan guru sehingga guru yang berasal dari sekolah yang berada di Provinsi yang sama juga memiliki perbedaan pandangan terhadap hal yang dijelaskan pada kurikulum. Kebijakan ini direspon guru dengan mengembangkan panduannya sendiri $(88,8 \%)$. Beberapa sekolah menunjukkan adanya tim pengembang kurikulum khusus dalam melakukan BDR tetapi beberapa sekolah juga tidak mengembangkan panduan tertentu.

Metode tugas dengan waktu pengumpulan tertentu merupakan metode utama pengumpulan data untuk mengukur pemahaman siswa terhadap proses belajar yang sudah dilakukan dan beberapa melakukan ujian menggunakan google form. Metode tugas merupakan penilaian formal yang melihat prestasi siswa dan lebih menekankan pada aspek kognitif siswa (Gagné et al., 2005). Beberapa metode lain dilakukan untuk mengukur aspek afektif siswa berupa angket/laporan aktivitas keseharian belajar, observasi/monitoring di kelas dan hasil pengerjaan tugas (kedisiplinan/ketepatan) dan aspek psikomotor berupa video/foto (karya/aktivitas siswa mengerjakan tugas), praktik langsung di kelas dan proyek (hasil tugas). Metode evaluasi yang dilakukan selama pengajaran berlangsung dengan cara menilai performa yang ditampilkan siswa selama pembelajaran (instructional assessment) merupakan penilaian informal (Gagné et al., 2005). Kurikulum juga menyediakan panduan nilai standar yang digunakan $(61,1 \%)$, cara pengelolaan nilai berdasarkan data yang didapatkan $(66,7 \%)$ dan langkah tindak lanjut berdasarkan hasil evaluasi (50\%).

\section{Komponen Guru}

Secara umum, guru memiliki kemampuan berupa pengetahuan dan keterampilan yang baik terkait halhal yang berkaitan dengan evaluasi belajar. Pada proses perencanaan, guru merasa mampu menyusun panduan $(61,1 \%)$ dan menyusun instrumen evaluasi $(66,7 \%)$. Pada proses pelaksanaan, guru merasa mampu memahami perbedaan evaluasi daring dan tatap muka (72,2\%), memanfaatkan LMS $(55,6 \%)$, menggunakan media evaluasi secara daring $(72,2 \%)$ dan berkolaborasi dengan orang tua $(66,7 \%)$. Guru juga menyadari perbedaan antara evaluasi belajar daring dan tatap muka berdasarkan prinsip Tobin et al. (2015), yaitu scope 
dan time equivalent dengan cara melakukan evaluasi tidak hanya satu kali ketika KBM terjadi di dalam kelas tetapi mengumpulkan data beberapa kali berdasarkan performa siswa di luar kelas. Meskipun belum sesuai pada beberapa prinsip, yaitu separating teaching from design dan instrumen applicability yang masih dengan cara guru memindahkan bentuk tugas atau persoalan tatap muka pada media daring dan menjadikan hasil pekerjaan siswa sebagai perilaku belajar siswa dan. Guru sudah bisa menyesuaikan diri dengan teknologi dan penggunaan LMS dengan upaya untuk mengembangkan keterampilan melalui pelatihan yang disediakan Kemdikbud atau Swasta.

Guru menyadari adanya antisipasi yang perlu dilakukan dalam melakukan evaluasi pembelajaran secara daring, yaitu perilaku siswa (seperti kemandirian/kejujuran/ketepatan hasil), penerapan metode oleh guru (seperti bahasa yang digunakan/aspek yang dievaluasi/kemudahan mengumpulkan), kemampuan/pemahaman siswa, perilaku orang tua (seperti mengerjakan tugas siswa) dan fasilitas (seperti perangkat/jaringan). Namun, guru tampaknya masih terlalu berfokus dalam memenuhi tanggung jawab untuk pemenuhan Kompetensi Dasar mata pelajaran yang diajarkannya masing-masing. Hal ini tampak dari setiap mata pelajaran memberikan tugas yang berbeda dengan waktu pengumpulan yang berbeda sehingga siswa merasa tugas yang diberikan terlalu banyak dan berdampak pada kedisiplinan untuk menyelesaikan setiap tugas sesuai waktu yang disepakati. Padahal evaluasi pembelajaran merupakan proses pengumpulan data dan informasi dalam membuat keputusan mengenai aktivitas-aktivitas pembelajaran meliputi program, kurikulum, metode pembelajaran dan aktivitas sekolah lainnya (Gage \& Berliner, 1998). Kurangnya kolaborasi antara guru mata pelajaran dalam memberikan tugas sebagai metode utama evaluasi pembelajaran secara daring mempengaruhi bagaimana respon siswa dan orang tua terhadap tugas dan guru belum mengantisipasi hal tersebut. Padahal konsep kolaborasi sebagai salah satu gaya dalam proses belajar mengajar yang dilakukan guru terbukti berpengaruh terhadap bagaimana siswa mempersepsi adanya lingkungan belajar yang penuh akan kerjasama yang dilakukan antar orang-orang yang terlibat dan meningkatkan kepuasan mengikuti pembelajaran (Sullivan et al., 2013). Penelitian lain juga menyebutkan bahwa kolaborasi yang dilakukan guru berpengaruh terhadap motivasi berprestasi siswa karena memungkinkan adanya komponen afektif yang hadir dari siswa dalam mempersepsikan kualitas pengajaran dengan melibatkan kolaborasi yang dilakukan antar guru, serta memungkinkan antar guru untuk saling mengevaluasi kinerja pengajaran yang dilakukan (Anwar et al., 2020).

\section{Komponen Siswa}

Perilaku siswa yang kurang mendukung proses evaluasi pembelajaran menjadi kendala utama yang dirasakan guru dan orang tua selama proses evaluasi belajar. Respon siswa yang menghambat proses pelaksanaan evaluasi, yaitu siswa tampak bosan, tidak mengerjakan tugas, terlambat mengumpulkan tugas, membantah/membohongi orang tua, membohongi guru, bolos KBM/main game/kebiasaan tidur berubah, serta hasil tugas tidak sesuai harapan/nilai menurun. Hal ini berkaitan dengan karakteristik siswa SMP yang berada pada fase remaja awal dimana terjadi perubahan yang cepat pada berbagai aspek (fisik, intelektual, sosio emosional) dan berbeda dengan siswa SMA yang yang berada fase remaja menengah yang lebih stabil dalam hal adaptasi dan integrasi dari perubahan pada masa sebelumnya. Remaja juga menjadi lebih masuk ke dalam kelompok pertemanan yang lebih kompleks dan menuntut konformitas, serta lebih mengarahkan pada bukan prestasi akademik (Santrock, 2014). Picciano et al. (2012) menjelaskan bahwa siswa membutuhkan kedewasaan, kedisiplinan dan kemampuan dasar keterampilan tertentu untuk bisa mengikuti pembelajaran secara daring, serta perlu adanya penyesuaian khusus dalam pelaksanaanya berdasarkan kebutuhan masingmasing siswa.

Respon yang diberikan siswa juga dapat dilihat sebagai dampak dari pemberian tugas yang terlalu banyak sebagai metode evaluasi belajar sedangkan pada waktu yang bersamaan siswa juga harus menghadiri KBM secara daring. Hal ini sejalan dengan penelitian Yates et al. (2020) yang menunjukkan bahwa selama pandemi Covid-19 siswa merasa meningkatnya beban tugas daripada ketika melakukannya secara langsung di 
sekolah dan kurangnya kolaborasi antar mata pelajaran dan Megawanti et al. (2020) bahwa siswa merasa terbebani dengan tugas yang banyak, waktu pengerjaan yang lebih sempit dan informasi pengumpulan tugas yang mendadak. Terlebih karena metode tugas merupakan penilaian formal yang lebih banyak mengukur aspek kognitif. Hal ini dapat berkaitan dengan self-efficacy siswa, yaitu keyakinan bahwa dirinya memiliki kompetensi untuk berhasil menyelesaikan tugas tertentu (Bandura, 1997). Ketika siswa diberikan banyak tugas dalam satu waktu hal tersebut dapat mempengaruhi keyakinan apakah dirinya dapat menyelesaikan tugas tersebut sesuai dengan waktu yang telah disepakati. Terlebih pengalaman keberhasilan dan kegagalan dalam penyelesaian tugas sebelumnya juga menjadi salah satu sumber self-efficacy (Bandura, 1997). Selfefficacy ini secara langsung atau tidak langsung mempengaruhi kesuksesan belajar siswa berupa (1) Activity choices, yaitu kecenderungan siswa untuk memilih mengerjakan tugas yang diyakini dapat diselesaikan dan menghindari tugas yang memungkinkan untuk gagal, (2) Goals, yaitu menetapkan tujuan yang tinggi untuk hal yang lebih yakin untuk dilakukan, serta (3) Effort and persistence, yaitu ketika siswa dengan self-efficacy yang lebih tinggi akan lebih berupaya, menggunakan strategi belajar yang efektif dan persistensi dalam menghadapi rintangan (Ormrod, 2016).

Berdasarkan cognitive load theory menunjukkan bahwa kelebihan beban kognitif dapat mengganggu motivasi belajar siswa dengan cara menghambat perhatian siswa pada materi pembelajaran (Kirschner et al., 2018). Schunk (2012) juga yang menjelaskan bahwa ketika siswa merasa kewalahan (overwhelmed) dalam mengupayakan penggunaan mental atau proses berpikir yang dibutuhkan dalam belajar akan berpengaruh pada turunnya motivasi belajar siswa. Penelitian Tyler-Smith (2006) menemukan bahwa beban kognitif yang berlebihan berkontribusi pada peralihan yang tinggi ketika satu minggu pertama kelas daring dilakukan. Hasil asesmen juga menunjukkan bahwa siswa mengerjakan tugas ketika tidak merasa terbebani dengan tugas yang diberikan, khususnya ketika diadakan hari atau minggu yang lebih memberikan tugas berbentuk keterampilan (life-skill) dengan penyajian tugas yang tampak lebih menarik. Pada dasarnya guru sudah melakukan langkah mengantisipasi perilaku siswa terhadap tugas dengan cara memberikan pemahaman/nasehat/ motivasi dan memastikan kejelasan tugas, aturan tertulis dan konsekuensi (reward and punishment) tetapi hal tersebut belum berhasil membuat siswa mau menyelesaikan tugas.

Latifah \& Supena (2021) menjelaskan bahwa memberikan waktu yang fleksibel dalam pengumpulan tugas dan memberikan tugas yang tidak menyulitkan peserta didik merupakan hal yang penting dilakukan ketika melakukan evaluasi belajara secara daring. Penelitian Yates et al. (2020) juga menemukan bahwa siswa merasa menikmati aktivitas pembelajaran yang dirancang lebih visual daripada teks tertulis secara menyenangkan dengan melibatkan anggota keluarga lainnya, seperti bermain musik bersama keluarga, mereview film yang ditonton bersama anggota keluarga dan aktivitas fisik bersama saudara. Hal ini sejalan dengan penelitian selama pandemi Covid-19 yang menjelaskan bahwa guru harus mencari metode-metode yang menyenangkan dalam menarik antusiasme siswa dalam mengerjakan tugas (Suryaman et al., 2020). Kim \& Frick (2011) menjelaskan beberapa hal yang mempengaruhi motivasi dan kepuasan siswa dalam melaksanakan tugas belajar secara daring, meliputi persepsi akan kaitan konten yang diberikan dengan kehidupan siswa, kemampuan penggunaan teknologi, motivasi belajar sebelum mengikuti pembelajaran daring, serta persepsi siswa bahwa pembelajaran secara daring merupakan hal yang benar untuk dilakukan. Hal ini menunjukkan bahwa respon siswa dipengaruhi bagaimana cara evaluasi pembelajaran secara daring diberikan kepada siswa.

\section{Komponen Orang Tua}

Pedoman pelaksanaan BDR dari Kemdikbud menuntut peran dan keterlibatan orang tua yang lebih dari pada sebelum BDR. Guru menilai bahwa orang tua sudah melakukan perannya yang lebih selama proses pelaksanaan evaluasi belajar, yaitu paling banyak melakukan diskusi secara aktif terkait tantangan dan kendala yang dialami $(88,9 \%)$ dan menyediakan sarana yang dibutuhkan $(88,9 \%)$, serta mendampingi siswa 
mengerjakan tugas $(83,3 \%)$. Namun, orang tua juga merasa dirinya beberapa kali dibohongi anaknya yang mengatakan sudah mengerjakan tugas. Peran penting orangtua dalam perkembangan remaja ialah melakukan pengawasan yang efektif, meliputi pengawasan dalam setting sosial, aktivitas, pertemanan, serta pengawasan akademik karena tingginya pengawasan orangtua berhubungan dengan tingginya pencapaian remaja di sekolah (Santrock, 2014). Terlebih karena selama BDR guru lebih sulit untuk dapat melakukan pengawasan secara langsung karena tidak berada di lokasi yang sama sehingga kemampuan orang tua untuk dapat melakukan pengawasan yang efektif menjadi penting dalam pelaksanaan evaluasi pembelajaran secara daring.

Perbedaan latar belakang pendidikan dan Sosial Ekonomi Status (SES) juga berkaitan dengan bagaimana orang tua memberikan respon terkait pendampingan siswa selama BDR. Kemampuan finansial yang menunjang pembelajaran anak di rumah diperlukan orang tua dalam berkolaborasi selama proses belajar secara daring dilakukan (Mansyur, 2020). Beberapa orang tua kurang berpartisipasi dalam pelaksanaan karena sibuk bekerja, tidak menghadiri pertemuan dengan guru, merasa jenuh/terbebani dengan BDR, serta menolak home visit karena bahaya penularan virus. Padahal sikap dan perilaku orang tua dan guru menjadi model bagi siswa (Ormrod, 2016) sehingga respon yang kurang mendukung proses pelaksanaan evaluasi pembelajaran orang tua dapat mempengaruhi respon siswa.

\section{Komponen Fasilitas}

Pelaksanaan proses evaluasi pembelajaran menggunakan berbagai media, meliputi media grup WhatsApp mata pelajaran, google classroom, google meet/hangout/zoom meeting, google form dan quizizz. Guru dan siswa tampaknya sudah mampu menyesuaikan diri dalam menggunakan teknologi dan berbagai media daring. Kebijakan pemerintah dengan memberikan kuota internet cukup berdampak besar terhadap permasalahan fasilitas meskipun pada beberapa daerah masih terdapat kendala jaringan. Beberapa orang tua kesulitan menggunakan media daring dan siswa kelas 7 kesulitan menyesuaikan diri dengan proses BDR karena belum pernah bertemu langsung dengan guru dan teman sekelas. Sekolah yang sudah menggunakan media daring sebelum kebijakan BDR diberlakukan tampak lebih mudah dan cepat dalam menyesuaikan diri sehingga sudah mulai berfokus pada permalahaan diluar fasilitas sedangkan sekolah yang baru memulai menggunakan media daring masih berada pada proses penyesuaian diri. Idealnya technology specialist dan LMS administrators merupakan pihak yang seharusnya ada pada evaluasi pembelajaran secara daring (Tobin et al., 2015). Keterbatasan ini masih dapat diatasi guru, siswa dan orang tua dengan keterampilan menggunakan media daring yang sudah dimiliki.

\section{KESIMPULAN}

Simpulan yang didapatkan pada setiap proses evaluasi pembelajaran secara daring sebagai berikut: (1) Pada proses perencanaan, kurikulum sudah memberikan arahan dan referensi untuk mengembangkan panduan dan pelaksanaan evaluasi pembelajaran dan guru memiliki kemampuan yang cukup untuk merancang proses evaluasi dan mempersiapkan fasilitas yang dibutuhkan; (2) Pada proses pelaksanaan, perlu adanya otonomi dan fleksibilitas kepada Disdik setempat, sekolah dan guru untuk mengembangkan dan mengimplementasikan kebijakan kurikulum yang dikeluarkan pemerintah. Guru sudah memiliki kemampuan (pengetahuan dan keterampilan) untuk melakukan evaluasi pembelajaran secara daring berdasarkan prinsip dan penggunaan berbagai media, meskipun masih diperlukan upaya untuk melakukan kolaborasi antara guru dengan mata pelajaran yang berbeda. Siswa memberikan respon yang kurang mendukung proses evaluasi dengan tidak mengerjakan atau terlambat mengumpulkan tugas karena merasa terbebani sehingga pentingnya peran guru dan orang tua sebagai upaya agar siswa memberikan respon yang mendukung efektivitas evaluasi. Orang tua sudah melakukan perannya yang lebih jika dibandingkan sebelum adanya kebijakan BDR dan fasilitas sudah lebih mendukung proses evaluasi pembelajaran dengan adanya sarana dan prasarana yang membantu Peran 
pengawasan yang efektif khususnya terkait pengerjaan dan penyelesaian tugas siswa masih perlu ditingkatkan dengan adanya mekanisme koordinasi pemberian, pemantauan dan pengumpulan tugas yang terintegrasi antara setiap guru mata pelajaran, siswa dan orang tua sebagai upaya meminimalisir jumlah tugas yang harus dikerjakan siswa untuk meningkatkan kemauan siswa dalam mengerjakan dan mengumpulkan tugas tepat waktu; (3) Pada proses setelah evaluasi, kurikulum sudah memberikan panduan mengenai cara pengelolaan nilai berdasarkan data yang didapatkan dan langkah tindak lanjut berdasarkan hasil evaluasi, serta guru merasa memiliki keterampilan dalam pengelolaan nilai.

\section{UCAPAN TERIMA KASIH}

Peneliti mengucapkan terima kasih kepada para guru SMP yang berpartisipasi dalam pengambilan data melalui proses diskusi dan pengisian kuesioner, serta para dosen dari Departemen Magister Profesi Psikologi Unpad dan mahasiswa Magister Psikologi Profesi Unpad yang turut terlibat dalam proses pengambilan data berupa bantuan dalam penyebaran informasi, memfasilitasi proses diskusi, melakukan review hasil analisis data dan memberikan masukan selama proses penelitian dilakukan.

\section{DAFTAR PUSTAKA}

Anwar, K., Asari, S., Husniah, R., \& Asmara, C. H. (2020). Students' Perceptions of Collaborative Team Teaching and Student Achievement Motivation. International Journal of Instruction, 14(1), 325-344. https://doi.org/10.29333/IJI.2021.14119A

Arifin, Z. (2012). Evaluasi Pembelajaran. Direktorat Jenderan Pendidikan Agama Islam.

Bandura, A. (1997). Self-Efficacy: The Exercise of Control. W.H. Freeman and Company.

Creswell, J. W., \& Creswell, J. D. (2018). Research Design (5th ed.). SAGE Publications, Inc.

Disdik, J. B. (2020). Pedoman Belajar dari Rumah SMA, SMK, SLB di Provinsi Jawa Barat Tahun Ajaran 2020/2021.

Fitrah, M., \& Ruslan, R. (2020). Eksplorasi Sistem Pelaksanaan Evaluasi Pembelajaran Di Sekolah Pada Masa Pandemi Covid-19 di Bima. Jurnal Basicedu, 5(1), 178-187. https://doi.org/10.31004/basicedu.v5i1.639

Gage, N. L., \& Berliner, D. C. (1998). Educational Psychology 6th Ed. Houghton Mifflin Company.

Gagné, R. ., Wager, W. ., Golas, K. ., \& Keller, J. . (2005). Principles of instructional design 5th Ed. Thomson/Wadsworth.

Hodges, C., Moore, S., Lockee, B., Trust, T., \& Bond, A. (2020). Remote Teaching and Online Learning. Educause Review, 1-15.

Howitt, D. (2010). Introduction to Qualitative Research Methods in Psychology 3rd Ed. Pearson.

Kemdikbud. (2020). Pedoman Pelaksanaan Belajar dari rumah Selama Darurat Bencana Covid-19 di Indonesia. Surat Edaran Sekretaris Jenderal No. 15 Tahun 2020. https://www.kemdikbud.go.id/main/files/download/5b9eda821425005.

Kim, K. J., \& Frick, T. (2011). Changes in student motivation during online learning. Journal of Educational Computing Research, 44(1), 1-23. https://doi.org/10.2190/EC.44.1.a

Kirschner, P. A., Sweller, J., Kirschner, F., \& Zambrano, J. R. (2018). From Cognitive Load Theory to Collaborative Cognitive Load Theory. International Journal of Computer-Supported Collaborative Learning, 13(2), 213-233. https://doi.org/10.1007/s11412-018-9277-y

Latifah, N., \& Supena, A. (2021). Analisis Attention Siswa Sekolah Dasar Dalam Pembelajaran Jarak Jauh di Masa Pandemi Covid-19. Jurnal Basicedu, 5(3), 1175-1182. 
1997 Pelaksanaan Evaluasi Pembelajaran secara Daring pada Belajar dari Rumah (BDR) jenjang Sekolah Menengah Pertama (SMP) - Annisa Sri Wandini, Fitriani Yustikasari Lubis

DOI: https://doi.org/10.31004/basicedu.v5i4.1113

https://doi.org/https://doi.org/10.31004/basicedu.v5i3.887

Mansyur, A. R. (2020). Dampak COVID-19 Terhadap Dinamika Pembelajaran Di Indonesia. Education and Learning Journal, 1(2), 113. https://doi.org/10.33096/eljour.v1i2.55

Megawanti, P., Megawati, E., \& Nurkhafifah, S. (2020). Persepsi Peserta Didik terhadap PJJ pada Masa Pandemi COVID-19. Jurnal Ilmiah Pendidikan, 7(2), 75-82.

Moore, M., Lockee, B., \& Burton, J. (2002). Measuring Success: Evaluation Strategies for Distance Education. Educause Quarterly, 25(1), 20-26.

Ormrod, J. (2016). Human Learning (7th ed.). Pearson.

Picciano, A. G., Seaman, J., Shea, P., \& Swan, K. (2012). Examining the extent and nature of online learning in American K-12 Education: The research initiatives of the Alfred P. Sloan foundation. Internet and Higher Education, 15(2), 127-135. https://doi.org/10.1016/j.iheduc.2011.07.004

Santrock, J. . (2014). Adolescence (15th ed.). McGraw-Hill.

Schunk, D. H. (2012). Learning Theories: An Educational Perspective (6th ed.). Pearson.

Sullivan, D., Colburn, M., \& Fox, D. E. (2013). The Influence Of Learning Styles On Student Perception And Satisfaction In A Highly Collaborative Team Taught Course. American Journal of Business Education (AJBE), 6(4), 429-438. https://doi.org/10.19030/ajbe.v6i4.7942

Suryaman, M., Cahyono, Y., Muliansyah, D., Bustani, O., Suryani, P., Fahlevi, M., Pramono, R., Purwanto, A., Purba, J. T., Munthe, A. P., Juliana, \& Harimurti, S. M. (2020). COVID-19 pandemic and home online learning system: Does it affect the quality of pharmacy school learning? Systematic Reviews in Pharmacy, 11(8), 524-530. https://doi.org/10.31838/srp.2020.8.74

Tobin, T. J., Mandernach, B. J., \& Taylor, A. H. (2015). Evaluating Online Teaching: Implementing Best Practices. Josey-Bass.

Tyler-Smith, K. (2006). Early attrition among first time eLearners: A review of factors that contribute to dropout, withdrawal and non-completion rates of adult learners undertaking eLearning programmes. Journal of Online Learning and Teaching, 2(2), 73-85.

Yates, A., Starkey, L., Egerton, B., \& Flueggen, F. (2020). High school students' experience of online learning during Covid-19: the influence of technology and pedagogy. Technology, Pedagogy and Education, 00(00), 1-15. https://doi.org/10.1080/1475939X.2020.1854337 